\title{
Anti-Immigrant Parties and Western European Society: Analyzing the Role of Immigration and Forecasting Voting1
}

Nate Breznau

Mannheim Centre for European Social Research (MZES), Mannheim, Germany

breznau.nate@gmail.com

\begin{abstract}
This paper analyzes and predicts the trajectory of immigration and anti-immigration parties in Western Europe from 1962 to 2035. Immigration increased steadily until the 2000s when it reached unprecedented levels. By 2017, countries in Western Europe average 11\% of votes cast for antiimmigrant parties. The percentage of the population that are first generation immigrants predicts between 50 and $94 \%$ of the variance in these votes across countries in Western Europe. Using methods of vector autoregression this paper analyzes the statistically causal role of immigration for predicting voting. Then using multilevel time-series models and qualitative cohort adjustments it forecasts both immigration and voting. Even the most conservative predictions suggest over $15 \%$ of the vote going to anti-immigrant parties by 2035. Given Europe's aging population and declining productivity, continued immigration to fill jobs among several segments of the labor market is necessary. This paper discusses the implications for the future of Europe drawing on theories of group dynamics and empirical research on politics and societies.
\end{abstract}

\footnotetext{
${ }^{1}$ The empirical analyses of this paper including predictions were made on March $17^{\text {th }}, 2018$. In the nature of open science, they are not updated despite elections that took place since then.
} 
In 2017, historical elections took place in Austria and Germany. The Austrian People's Party, the centerright mainstream party, ran a campaign explicitly targeting immigrants and immigration issues. Rather than 'taking-back' votes from the hardcore anti-immigrant Freedom Party, both parties dominated the Austrian polls with a combined $60 \%$ of the vote. Their ruling coalition affords an anti-immigrant party its most powerful national position in European post-war history. The other was the sudden rise of the xenophobic Alternative for Germany (AfD) gaining almost 13\% of the national vote. The first time any populist ethno-centric party finished third in a German national election since the Nazis. Although, the lessons of the destructive wars make these events hard to imagine, they are not surprising looking at empirical trends in Western Europe since the 1960s.

Anti-immigrant parties are a set of parties that scholars often label as "radical right" (Mudde 2010) or "neo-nationalist" (Eger and Valdez 2015). Whatever the label, there exists two common components of this increasingly successful type of political party in Western Europe. One is populism and the other is antiimmigrant political positioning. Thus, for simplicity, I use anti-immigrant parties to capture all parties putting forth a claim of 'us' (the national people) against 'them' (the outsiders, or undeserving) ${ }^{2}$. In particular, these parties oppose immigrants and their descendants, often opposition increases as a function of phenotypical and cultural divergence, e.g., skin color and Islamic-country origins.

Immigration and the success of anti-immigrant parties work in tandem. Figure 1 shows the percentage of the population that are first generation immigrant and the national vote share going to anti-immigrant parties on average since 1962. Between 1962 and 2017, immigrants as a share of the total population increased from four to $15 \%$ and the average vote share for anti-immigrant parties increased from two to $11 \%$. The pattern is striking and is likely evidence of what scholars suggest is part of a causal relationship (Halla, Wagner, and Zweimüller 2017). Immigration or the threat of immigration seems to be a necessary condition for these parties' successes as observed by Knigge (1998). Anti-immigrant parties scapegoat immigrants (Cochrane and Nevitte 2014). They play on immigrants and immigration as threating national group identity, economic resources, culture and values, and possibly causing violence (see also reviews in Berg 2015; Eger and Bohman 2016; Hainmueller and Hopkins 2014). They are the manifestation of the emotional and attitudinal reactions among natives over the sanctity of their national in-group (Hjerm 1998; Kaufmann 2008; Pehrson, Brown, and Zagefka 2009; Reeskens and Wright 2013; Wessendorf 2008). It appears that the phenomenon of immigration helps antiimmigrant parties bring together voting by authoritarian and racist individuals, those who think immigrants and immigration threaten individual or societal prosperity and those frustrated with elites making decisions for 'us' - especially when they come from other countries (for example via EU governance) (Art 2011; Cutts, Ford, and Goodwin 2011; Golder 2016).

\footnotetext{
${ }^{2}$ See Table 2 in the Appendix for coding. This label is also used elsewhere (van der Brug, Fennema, and Tillie 2000), applies regardless of whether voters anti-immigrant, and refers to many parties that are simultaneously anti-elite (van der Brug and Meindert 2003; Rydgren 2005).
} 


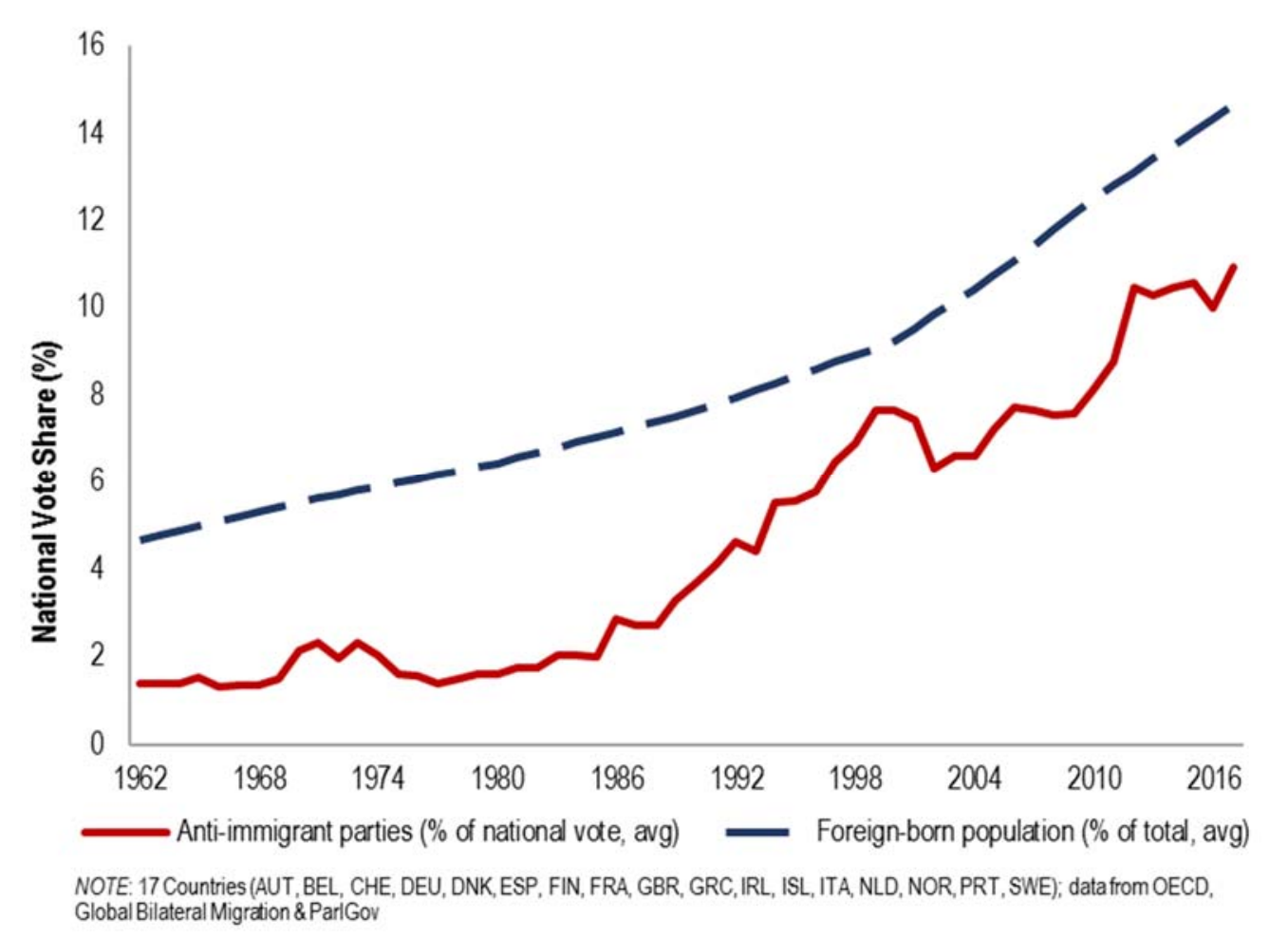

A primary cause of immigration to Western Europe is attraction to economic development. Western Europe had the richest post-industrial concentration of societies in the world for nearly a century. Furthermore, during the 1960s and 70s some countries explicitly invited immigrants to fill demands for labor generated by post-war growth. The invited guest workers often decided to remain and bring their families. Over time, immigrants of the first, second and third generation were a stable fixture in Western European societies. Counting the second generation, most countries are more than 15\% foreign-born with Great Britain and Austria as high as 30\% (Agafiţei and Ivan 2016). Although GDP growth stagnated since the 60s, the demand for labor is increasing steadily with Western Europe's aging populations (Castles 2006). The support ratio of workers to pensioners is not sustainable and fell in the past decades. There simply is not enough young workers to provide the health, retail, repair and various other services demanded by pensioners. Moreover, younger workers are necessary to pay into social insurance. Most country's multi- pillar systems draw heavily on pay-as-you-go and public tax funding (Ebbinghaus and Whiteside 2012). Without new workers, the state lacks funds to make good on retirement income or health insurance owed to pensioners (UN 2001).

Higher productive output per worker would reduce the need for more workers paying into social security. Given the trend in Gross Domestic Product per capita (GDP) across Western Europe this unlikely to happen. Figure 2 demonstrates the factors of the falling support ratio. The higher the proportion of those over 64 (dotted line) and the lower the GDP growth year-over-year (solid line) the greater the demand for workers from abroad. To the right of the vertical line in Figure 2 are values predicted by the Organization for Economic Co-operation and Development (OECD). They signal a high demand for labor that will be unmet locally due to aging. Even if productivity expanded, this would not solve the demand for workers to service the needs of the 
aged population. Even if machines fill these jobs to some extent, it will take years to perfect machine-provision, trust in machine assistants is likely low and they cannot perform all tasks ${ }^{3}$.

\section{Figure 2. Population Aging and per capita GDP Growth in Western Europe, 1962-2035}

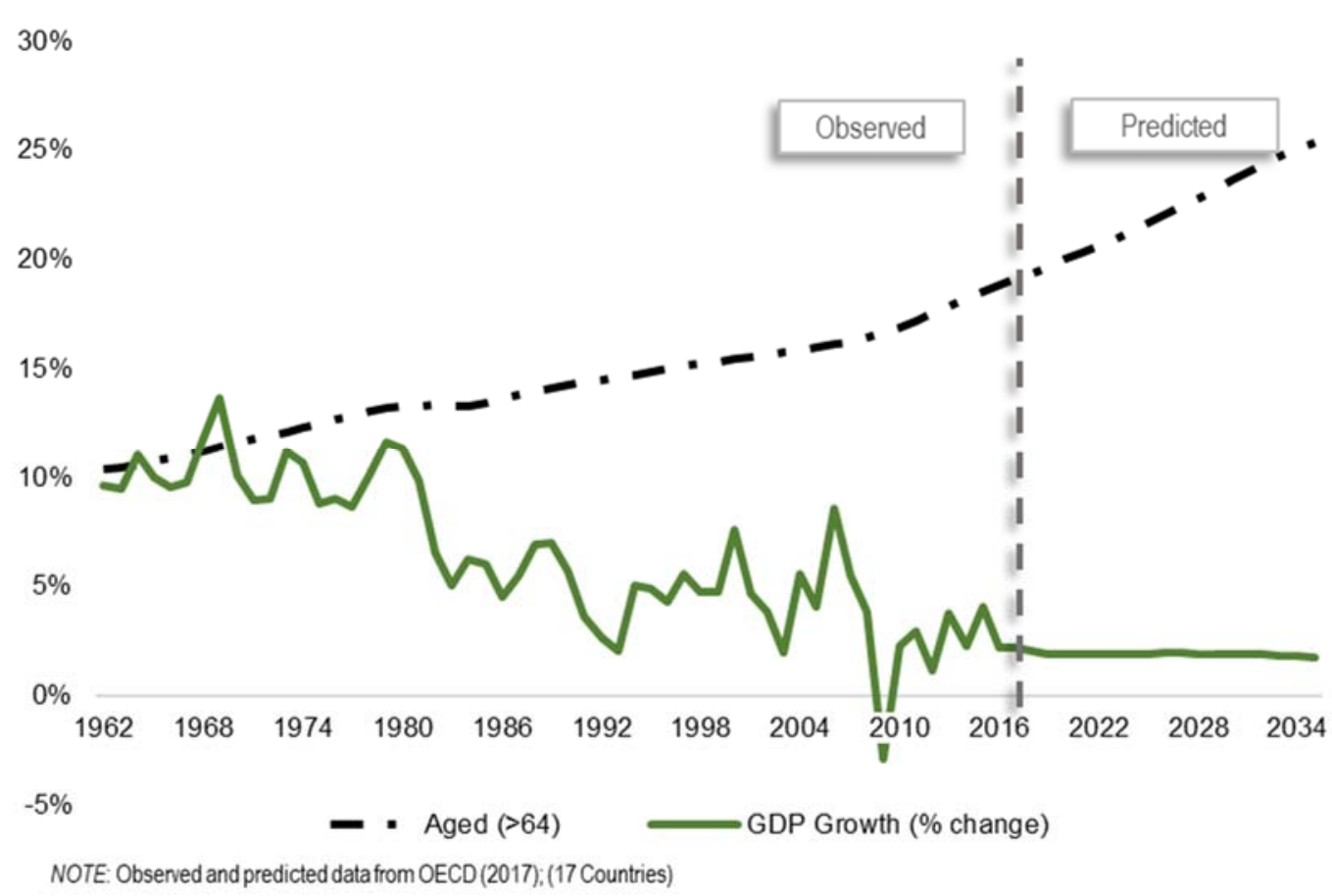

Given support ratio and labor demand for immigrants plus the supply of potential immigrants, the number of first generation immigrants must continue to increase in Western Europe. This immediately suggests the vote share of anti-immigrant parties also will increase, as suggested by the trend in Figure 1.

The first aim of this paper is to test if immigration is necessary to explain the increase in voting for antiimmigrant parties. To do this I ran vector autoregression models and simulated socks to the share of immigrants on voting from 1962 to 2017 . The results of this first step ascribe significant power to the share of foreign-born population in explaining anti-immigrant voting. Therefore, I engaged in multilevel regression models of immigration on anti-immigrant vote share and used them to forecast the anti-immigrant party vote share until 2035. Given that anti-immigrant parties appear to be at different phases of development in each country as of 2017, I developed a qualitative cohort model of parties to infer what might happen in countries with new antiimmigrant party voting if they follow similar trajectories as those with longer histories of anti-immigrant voting. I then applied these cohort adjustments to the multilevel predictions to provide a range of forecasts. The variable anti-immigrant vote share is a proxy for powerful political and social changes taking place in Western Europe, if not Europe as a whole. Therefore, I devote the final section of the paper to the implications of these changes. I provide all data and code in an Online Technical Appendix.

\footnotetext{
${ }^{3}$ Aged persons may not accept personal care or services from robots (e.g., automated check-out systems, personal health care practitioners, IT/computer support or help, and so forth) (Broadbent, Stafford, and MacDonald 2009). Moreover, the production and maintenance of robots creates jobs (Autor 2015). Government and voters (if not economists) may tax, regulate or limit them in various ways to preserve jobs, or to prevent easily foreseeable crises given available data (Abbott and Bogenschneider 2018; Halal, Kolber, and Davies 2016).
} 


\section{Testing And Forecasting Anti-Immigrant Party Success in Western Europe}

In order to test for an effect of immigration and to forecast anti-immigrant party vote shares from 2018-2035, I use the variables listed in Table 1 measured from 1962-2017 in 17 countries covering $99.88 \%$ of Western Europe's population. These are all countries for which data are available. It is prudent to predict only over a short term because errors in prediction theoretically increase exponentially over time, so I select 2035 as a reasonable forecast target.

\section{Table 1. Descriptive Statistics by Level}

\begin{tabular}{|c|c|c|c|c|c|c|c|}
\hline Overall & & & & & & & \\
\hline variable name & measure & mean & s.d. & $\min$ & $\max$ & $\mathrm{N}$ & ICC \\
\hline Anti_share & $\begin{array}{l}\text { Percent of national vote share } \\
\text { for Anti-Immigrant Parties }\end{array}$ & 4.71 & 7.33 & 0 & 31.30 & 927 & $47 \%$ \\
\hline Foreign_born & $\begin{array}{l}\text { Percent of population born } \\
\text { abroad }\end{array}$ & 7.92 & 5.34 & 0.59 & 30.16 & 952 & $62 \%$ \\
\hline Aged & $\begin{array}{l}\text { Percent of population over } 64 \\
\text { years of age }\end{array}$ & 14.26 & 2.95 & 7.50 & 22.60 & 952 & $26 \%$ \\
\hline GDP & $\begin{array}{l}\text { Gross Domestic Product } \\
\text { (GDP) per capita in } 2017 \text { US\$ }\end{array}$ & 21,578 & 14,465 & 2,042 & 72,772 & 828 & $6 \%$ \\
\hline GDP_growth & $\begin{array}{l}\text { Percent growth of GDP } \\
\text { since t-1 }\end{array}$ & 5.75 & 4.03 & -10.15 & 35.79 & 814 & $0 \%$ \\
\hline Within-country & & & & & & & \\
\hline Anti_share & & 0 & 5.28 & -9.25 & 23.18 & 927 & \\
\hline Foreign_born & & 0 & 3.26 & -6.56 & 10.14 & 952 & \\
\hline Aged & & 0 & 2.52 & -6.04 & 8.01 & 952 & \\
\hline GDP & & 0 & 13,888 & $-25,265$ & 49,614 & 828 & \\
\hline GDP_growth & & 0 & 3.98 & -16.74 & 28.00 & 814 & \\
\hline Between-country & & & & & & & \\
\hline Anti_share & & 0 & 5.23 & 0 & 19.40 & 17 & \\
\hline Foreign_born & & 0 & 4.35 & 2.20 & 20.80 & 17 & \\
\hline Aged & & 0 & 1.58 & 10.66 & 16.60 & 17 & \\
\hline GDP & & 0 & 4,208 & 14,498 & 30,674 & 17 & \\
\hline GDP_growth & & 0 & 0.66 & 4.89 & 7.79 & 17 & \\
\hline
\end{tabular}

Note: ICC is Intra-class Correlation - the percentage of the total variance that occurs between-countries; 17 countries are Austria, Belgium, Switzerland, Germany, Denmark, Spain, Finland, France, Great Britain, Greece, Ireland, Iceland, Italy, The Netherlands, Norway, Portugal, and Sweden; data sources as follows: Anti-Immigrant Party Vote (Döring and Manow 2016) see Table 2 Appendix; Foreign-born (OECD 2017b, 2017c; Özden et al. 2011); GDP (OECD 2018); GDP forecasted (OECD 2017a); Aged and Aged forecasted (OECD 2010; UN 2017).

\section{Vector Autoregression}

The logic behind forecasting is that immigration has a causal role. Therefore, there is a burden on the percent foreign_born as a variable, as it proxies immigration processes theoretically necessary for antiimmigrant parties to experience success. Therefore, I first engage in time-series regression modeling controlling for auto correlation to see if statistics substantiate this theoretical logic. I attempt to simulate what a shock in 
foreign-born would have caused to the observed values of anti_share from 1962-2017 using vector autoregression (VAR). If a foreign_born shock successfully simulates an increase in anti_share in impulseresponse functions of the VAR, then I have evidence that regardless of exact causal processes, foreign_born increase is necessary statistically to explain anti_share increases (Sims 1980). This is evidence necessary to engage in forecasting models.

The VAR corrects for serially correlated errors and their cross-lags produced from path dependency, i.e., autocorrelation. It allows a researcher to specify a set of potentially causal variables in a predictive model without knowing the exact nature of the causal processes. A kind of 'everything-causes-everything' model that yields consistent time-series estimates (Freeman, Williams, and Lin 1989). It is particularly useful for forecasting how a change in one variable might lead to changes throughout the system if not feedback on itself. The VAR is a series of regression equations stacked together. Rather than write each of these equations I express the entire system in simplified matrix notation.

$$
Y(\text { all endogenous variables })=B(\text { coefficients }) Z(\text { lagged } Y \text { variables })+U(\text { errors })
$$

In Equation 1, $Y$ is a matrix of separate equations, one for each endogenous variable and the different potential configurations of predictor variables (for how equations stack, see Lütkepohl 2005:70). This leads to a matrix of coefficients noted as $B$, one for each instance of each lagged variable. Every endogenous variable appears as a lagged variable including each variables' lagged versions predicting its current version, plus a stacked matrix of $U$ errors. The constants and exogenous variables are present in all equations but not shown in Equation 1. When combined, the VAR equations give overall coefficient estimates. The VAR runs separately for each country. Given that many countries do not have anti-immigrant voting for large portions of their histories I trim the series to within 5 years of the first instance of anti-immigrant voting, otherwise I would predict zero with zero, which is not useful. Therefore, for several countries there is little or nothing to simulate. Moreover, given that all the lagged variables quickly use up degrees of freedom I must select variables carefully. However, the auto-correlation corrections in VAR allows for inclusion of foreign_born, GDP_growth and aged without worry about their endogeneity, which is otherwise quite high with within and between-country correlations over 0.5 (see Online Technical Appendix ${ }^{4}$ ).

Readers may view the regression coefficients by country in the Online Technical Appendix. In order to use these results I apply Granger logic and graph impulse-response functions simulating what happens to anti_vote shares if a shock increase of one-percentage point in foreign_born occurred. Figure 3 displays the results, but only for those countries where the time series are long enough to provide the degrees of freedom for estimation.

\footnotetext{
${ }^{4}$ Planned upon publication.
} 


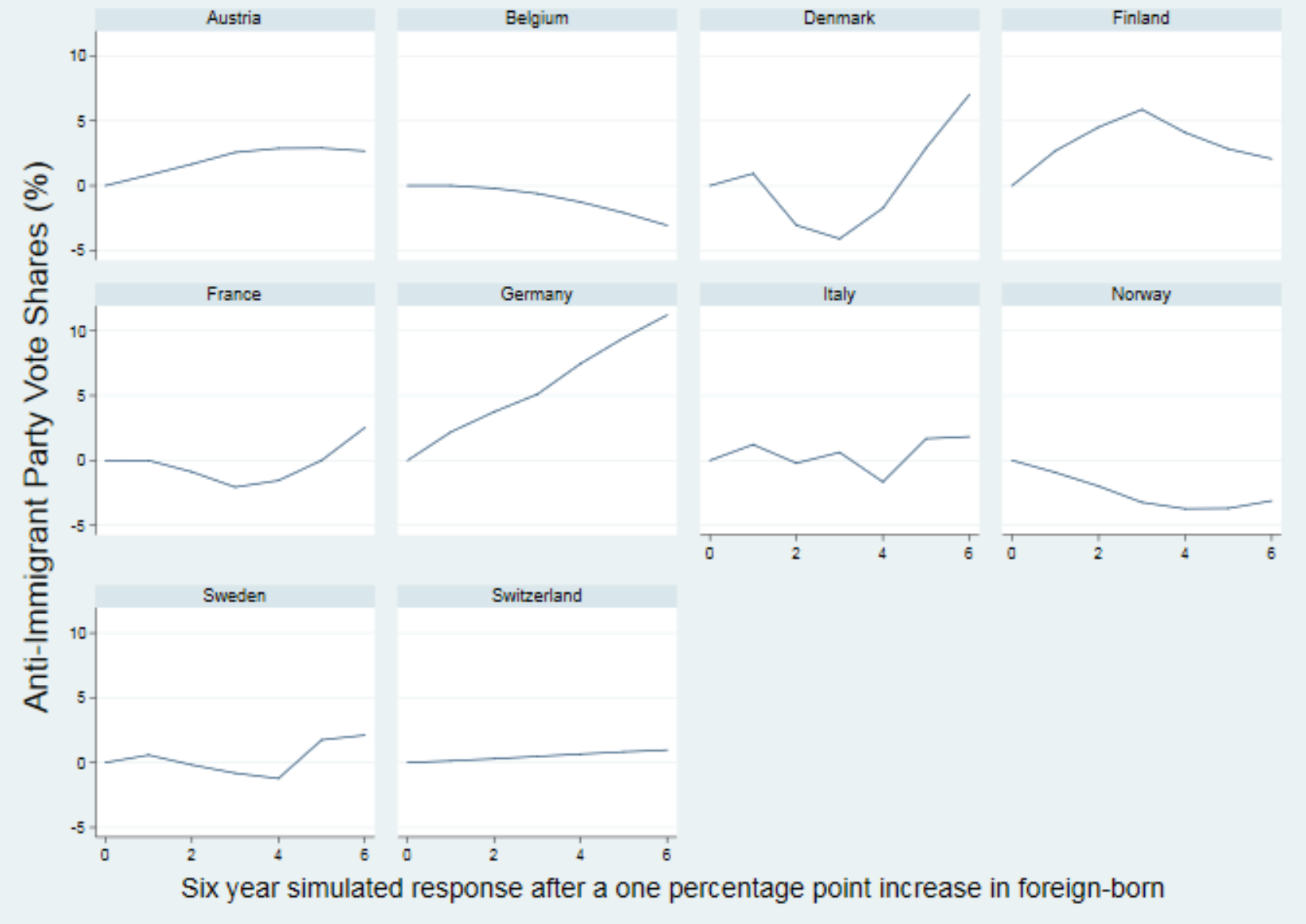

In Figure 3, eight out of 10 countries have predicted increases in anti-immigrant vote shares over the course of six years. The exceptions are Belgium and Norway. These impulse-response predictions say nothing about the time trend, as anti_share and foreign_born increased over time in Belgium and Norway. They point to the fact that other variables in the VAR can account for increases instead of foreign_born in these two countries. The shocks produce a range of effects from a massive 10 percentage point increase in Germany to a one point increase in Switzerland. These results in no way confirm causality, they simply offer evidence that increases in foreign_born predict increases in anti_share after correcting for autocorrelation and endogeneity; they are, as Granger would say, 'statistically causal'. However, they are evidence necessary to rely on the variable foreign_born in forecasting anti_share.

My forecasting also relies on time to capture path dependency of the concept that anti-immigrant parties tend to increase their vote share after arriving 'on the menu' in a given country. To test path dependency, I simulate a one-percentage point gain in anti_share impacting later versions of anti_share over six years. Figure 4 demonstrates of course that a one-percentage point increase in anti_share remains after one year in most countries. However, it does not lead to a further increase in anti_share except for a tiny short-term bump $(\sim 0.15 \%)$ in Finland and Switzerland. For most countries, there is a declining return to this shock. Here it becomes clear that anti_share alone is not path dependent. Both increases in anti_share and foreign_born, are necessary to explain the observed increases in anti_share. 


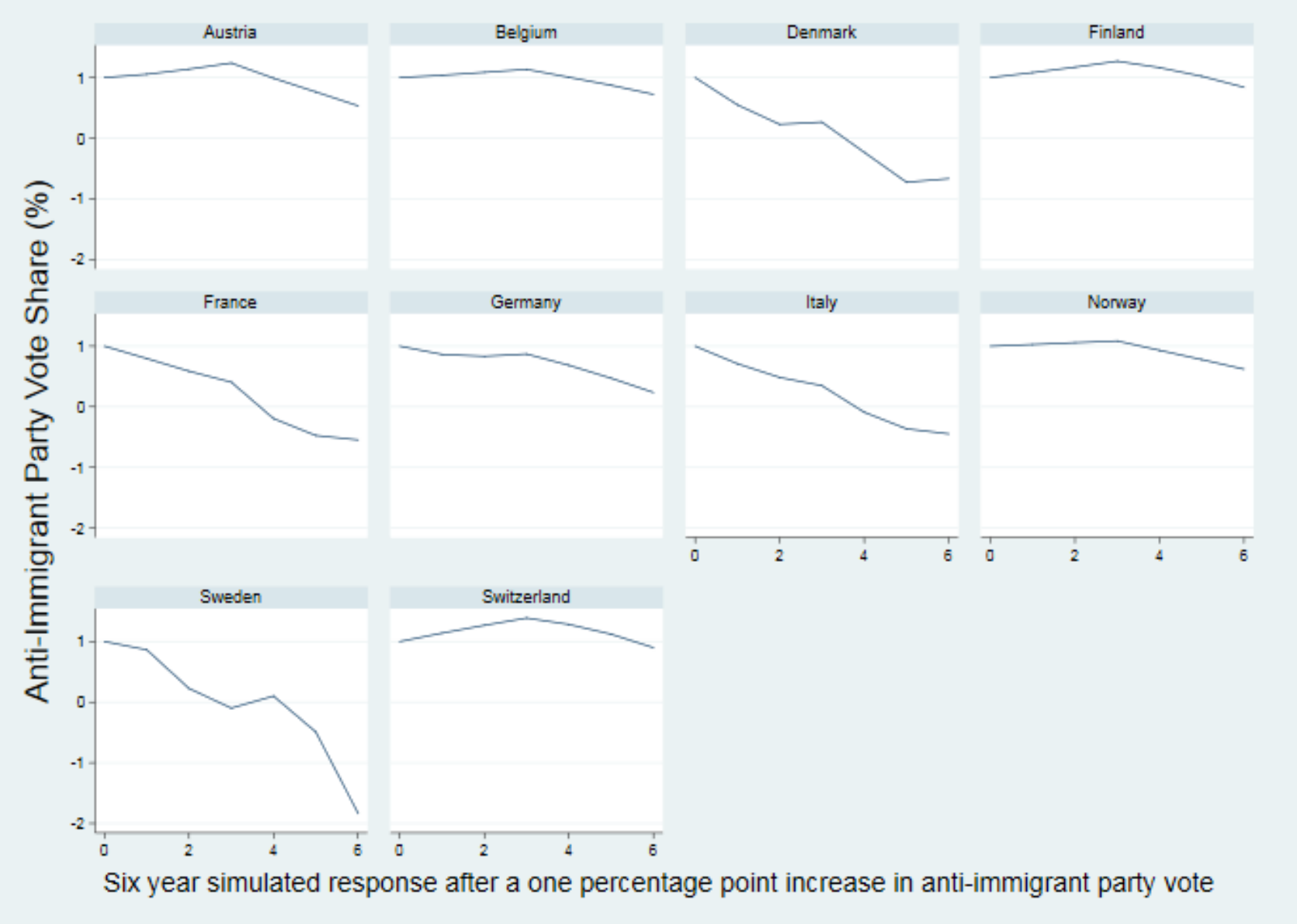

Given the goal of forecasting anti-immigrant voting in Western Europe as a whole, I collapse the time series of all 17 countries into one time series. In this Western Europe time series I run a VAR and then simulate shocks of foreign_born and anti_vote, but this time over the course of 10 years as the series is complete form 1962-2017. Results in Figure 5 show that a one-percentage point increase in foreign_born leads to a fourpercentage point anti_share increase over eight years. This starts to decline after eight years, a prediction that is not surprising because foreign_born increases rather steadily over time in the time series, Only a one point increase wears off in its effect without further increases in foreign_born. As there is wide variation at the country level shown in Figure 4, I consider a one standard deviation confidence interval, shown as a grey band in Figures 5 and 6. This suggests the impulse could predict only a 2.5 percentage point vote gain or as much as seven. 


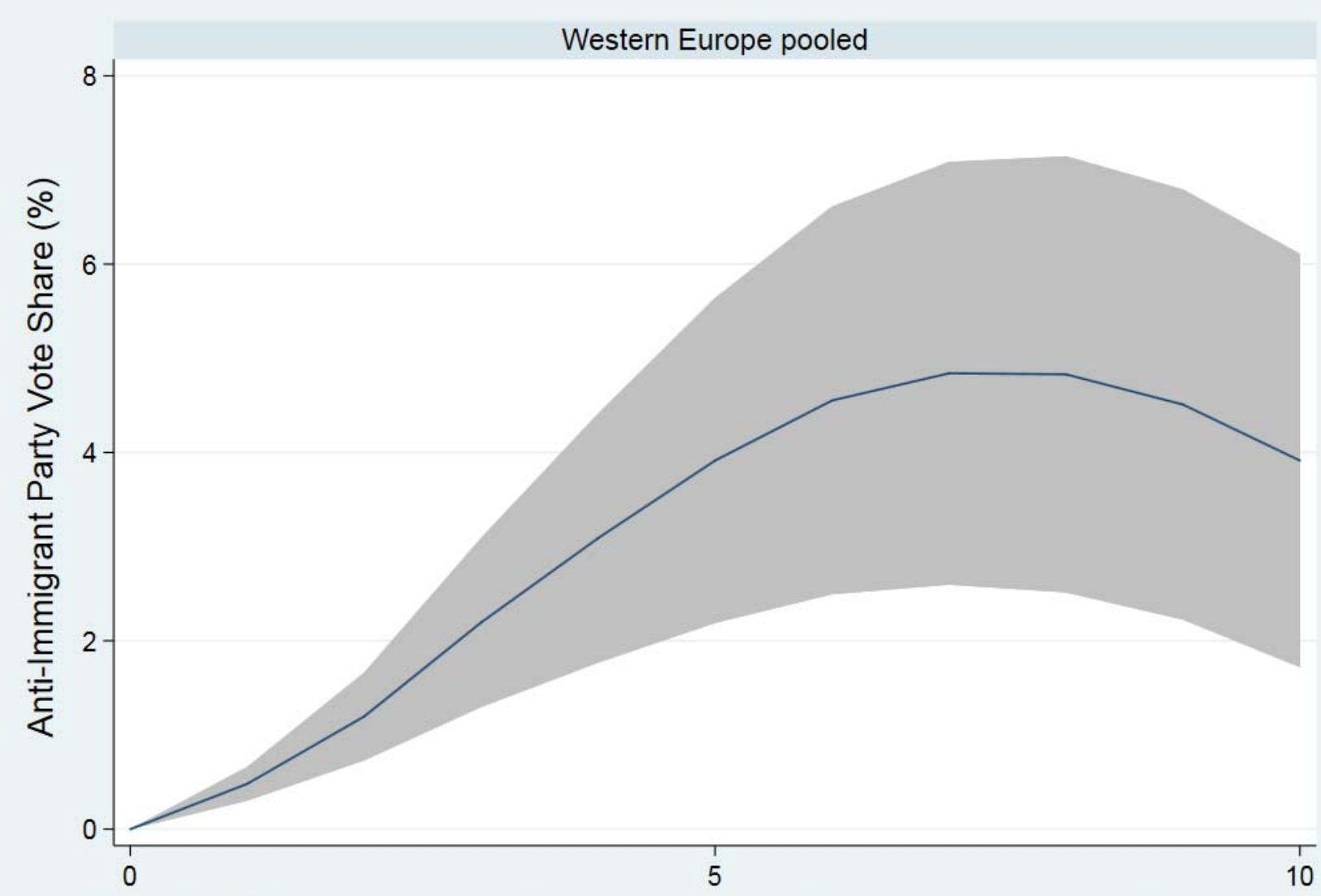

Simulated 10-year response after a one percentage point increase in foreign-born

Finally, Figure 6 demonstrates that considering the evidence across Europe, there is a small increase, maybe half-a-percentage point over the next four years after a simulated shock in anti_share. This eventually starts to decline and returns to zero after about 8 years. This suggests counterfactually that without increases in foreign_born, anti-immigrant party vote shares are not sustainable, certainly not in terms of sustained growth. Although not inferentially causal, this highlights the importance of foreign-born populations and lends credence to my approach to forecasting. Statistically speaking, after controlling for autocorrelation and bi-directional effects of variables, increases in the percentage of the population that are foreign-born were necessary to produce increases in anti-immigrant party vote shares between 1962 and 2017. 


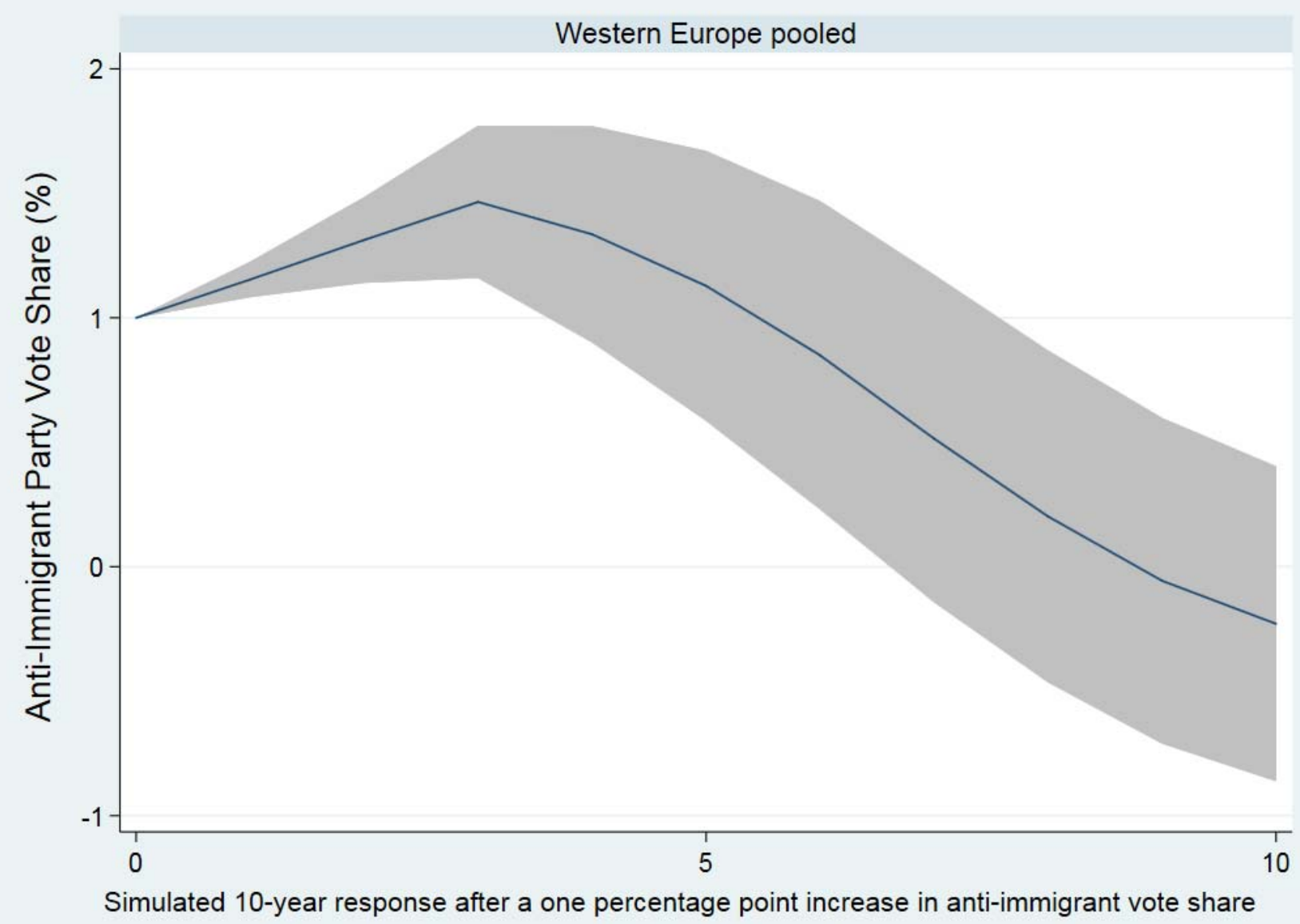

These shock predictions suggest what might happen after 2017. If immigration increases and all other factors continue on their standard trajectories, then one or two point increases in foreign_born occurring through 2025 will result in an eight percentage point increase in anti_share by 2035, in other words around $20 \%$ of the vote share going to anti-immigrant parties.

\section{Foreign-born as a Percentage of the Population}

To predict voting after 2017 I first need to predict percent foreign_born as a variable from 2018 to 2035. To do so, I follow a simple deterministic forecast because path dependency is the expected trajectory barring accurate knowledge about future shocks (Pierson 2000). Moreover, the inevitable breakdown of welfare state sustainability and the absolute need for workers to serve aging populations necessitate immigration suggesting it will continue as it has. I model this determinism at first using multilevel time-series regressions allowing for both fixed and random components.

Immigration is a function of previous immigration due to path dependency and family reunification practices, creating endogeneity between immigration and time. Although time is not the causal factor, it is a proxy for immigrant trajectories. In addition, immigration is a function of economic development as a supplyside push factor and support ratio as a demand-side pull factor ${ }^{5}$. From the supply-side, Western Europe has the

\footnotetext{
${ }^{5}$ The dependency ratio restricted to those over 65 (i.e., excluding the young).
} 
highest country per capita GDP average in the world (World Bank ${ }^{6}$ ) in addition to stable democratic, rule of law societies making it one of the most popular migration destinations. The supply of potential migrants is thus roughly equal for all of Western Europe. While immigrants try to move where they have families or perhaps possess language skills, the larger goal is to get into Western Europe (i.e., into rich, stable societies). If one country strongly restricts immigration, it is not likely to change the supply of potential immigrants wanting to come to Western Europe overall.

The predicted support ratio in 2050 with zero net migration is $2: 1$, which poses grave threats to the standard of living for pensioners. The historical ratio was 4:1 (four workers for every pensioner). To recover a 4:1 ratio demands 25 million immigrants per year into Europe (UN 2001:26-28). Although this number is theoretically possible, it is astronomical in comparison to current rates of less than 2 million per year. Moreover, it would result in a foreign-born population of $75 \%$ by 2050 . However, partial closure of the predicted ratio in 2050 from 2:1 to 3:1 requires only 4 to 6 million immigrants per year, which sounds more realistic and results in a foreign-born population around $30 \%$. In addition, these immigrants would provide the labor needed to fill the variety of jobs supporting an aging population. Moreover, security and borders eventually should shift to the purview of EU governance, and this means immigration will increase out of EU-self-preservation. The EU might fail economically or politically without immigrants to offset a plummeting absolute and relative population to the rest of the world, creating further strength on the demand side (Demeny 2003) ${ }^{7}$. These facts suggest that time and the percentage of the population that are aged (over 64) are key variables.

Equation 2 formally represents this theoretical model of immigration, where a counter for year captures time and has a fixed-slope for all countries to get at a supply-side effect plus any European-wide trend. Then I allow each country $(j)$ to have a unique slope for counter and aged across country-time points $(i)$. Aged only has random-slopes because this demand-side factor is country-specific whereas counter should capture the increase in global supply and demand over time.

$$
Y(\text { foreign_born })_{i j}=\beta_{0}+\beta_{1} X(\text { counter })_{i j}+\mu_{1 j} X(\text { counter })_{i j}+\mu_{2 j} X(\text { aged })_{i j}+u_{0 j}+\epsilon_{i}
$$

Results of a multilevel (i.e., general least squares) regression estimating Equation 2 are in Table 3 in the Appendix. To give a confidence interval I use the low and high standard errors of the predicted point estimates, leading to three predictions for each country (low, mid and high). The intra-country correlation of the estimated and observed time-series is very strong, ranging from the highest in Portugal (0.99) and Denmark (0.97) to the lowest in Greece $(0.72)^{8}$ and France (0.74) with an average of 0.90 across the 17 countries (12 are above 0.88 ). Greece is an outlier because migration declined

\footnotetext{
${ }^{6} \mathrm{https}: / /$ data.worldbank.org/indicator/ (author's calculations, accessed 20.02.2018)

${ }^{7}$ Coupled with the demands of an aging population, immigration should increase, if not Europe fails and then this exercise is moot.

${ }^{8}$ Greece is peculiar because it is the only country where migration declined dramatically after the financial crisis and the austerity conditions of the bailout.
} 
dramatically after the financial crisis and the austerity conditions of the bailout. These correlations amount to within-country r-squared values of 0.52 through 0.94 . This is evidence that the predictions are high quality for the observed portion of the data.

International statistical agencies avoid predicting first generation immigrant populations, most likely for political reasons. Yet, an experimental area of Eurostat predicts net migration for 28 European countries through 2080 (Eurostat 2018). I cannot adjudicate between in and out-migration, but the Eurostat measure allows me to proxy foreign_born estimates using a fixed population growth rate and a 1.1 scaling factor on net migration under the assumption that out-migration includes more native born than in-migration. It turns out that my predictions are similar to the Eurostat-implied predictions, the 'high' prediction series is nearly identical and the 'low' and 'middle' predictions are slightly conservative (i.e., underestimated), suggesting plausibility. See Figure 7 in Appendix.

\section{Anti-Immigrant Party Vote Shares through 2035}

The vote shares of anti-immigrant parties (anti_share) are a function of immigration. Moreover, they are path dependent. Once anti-immigrant parties gain a small portion of the vote share, they tend to increase their vote share because their message gains attention if not legitimacy in the public eye; however, as shown above this only sustains with a simultaneous increase in immigration. Anti-immigrant parties sometimes function as a source for voter frustration; therefore, they are also a function of economic factors such as GDP growth. In most societies, anti-immigrant parties did not exist in the early part of the time series (1962-1990) and many only gained significant vote shares in the 2000s or 2010s. Therefore, there are time-series with long strings of zeros. During these zero periods, foreign_born increased but cannot mathematically correlate with anti_vote. This means foreign_born has two effects on voting, one applicable to the entire time period 19622017, and another beginning at the time that anti-immigrant parties come into existence (I label this foreign_anti) calculated as 0 for years without any anti-immigrant party vote share and equal to foreign_born for years with a share greater than zero. This decision grows out of strong endogeneity between foreign_born, GDP, counter and aged. Foreign_born easily proxies the others for the full time-series. Their grand-correlations are between 0.50 and 0.63 and their within-country correlations are even higher ranging from 0.69 to 0.99 .

I want to get at the specific variance of foreign_born that explains anti-immigrant voting and eschew the endogenous remainder. Therefore, I take partial correlations of the other variables. To allow for the possibility of GDP influencing frustration voting, I include change in GDP in the models over the past 3 years (GDP_growth). The final formal expression of the multilevel regression is Equation 3:

$$
\begin{aligned}
Y(\text { anti_vote })_{i j}= & \beta_{0}+\beta_{1} X(\text { aged })_{i j}+\beta_{2} X(G D P)_{i j}+\mu_{3 j} X\left(G D P \_g r o w t h\right)_{i j}+ \\
& \mu_{4 j} X(\text { foreign_born })_{i j}+\mu_{5 j} X(\text { foreign_ant })_{i j}+u_{0 j}+\epsilon_{i}
\end{aligned}
$$

Where aged is a residual after partial correlation with foreign_born within each country, and GDP and GDP_growth are residuals of partial correlations with aged and foreign_born; calculated between 
countries for GDP to reflect a universal supply and demand driver and within-countries for GDP_growth to reflect each countries' context-dependent frustration voting. I run Equation 3 for the low and high 95\% confidence foreign_anti estimates. Although forecasted anti_vote from 2018-2035 for each country varies, the overall prediction is an increase in anti-immigrant party vote share in Western Europe shown in Figure 8. The results of the regression for Equation 2 are in Table 4 in the Appendix and all data in the Online Technical Appendix.

\section{Figure 8. Anti-Immigrant Vote Share Predictions, 2018-2035}

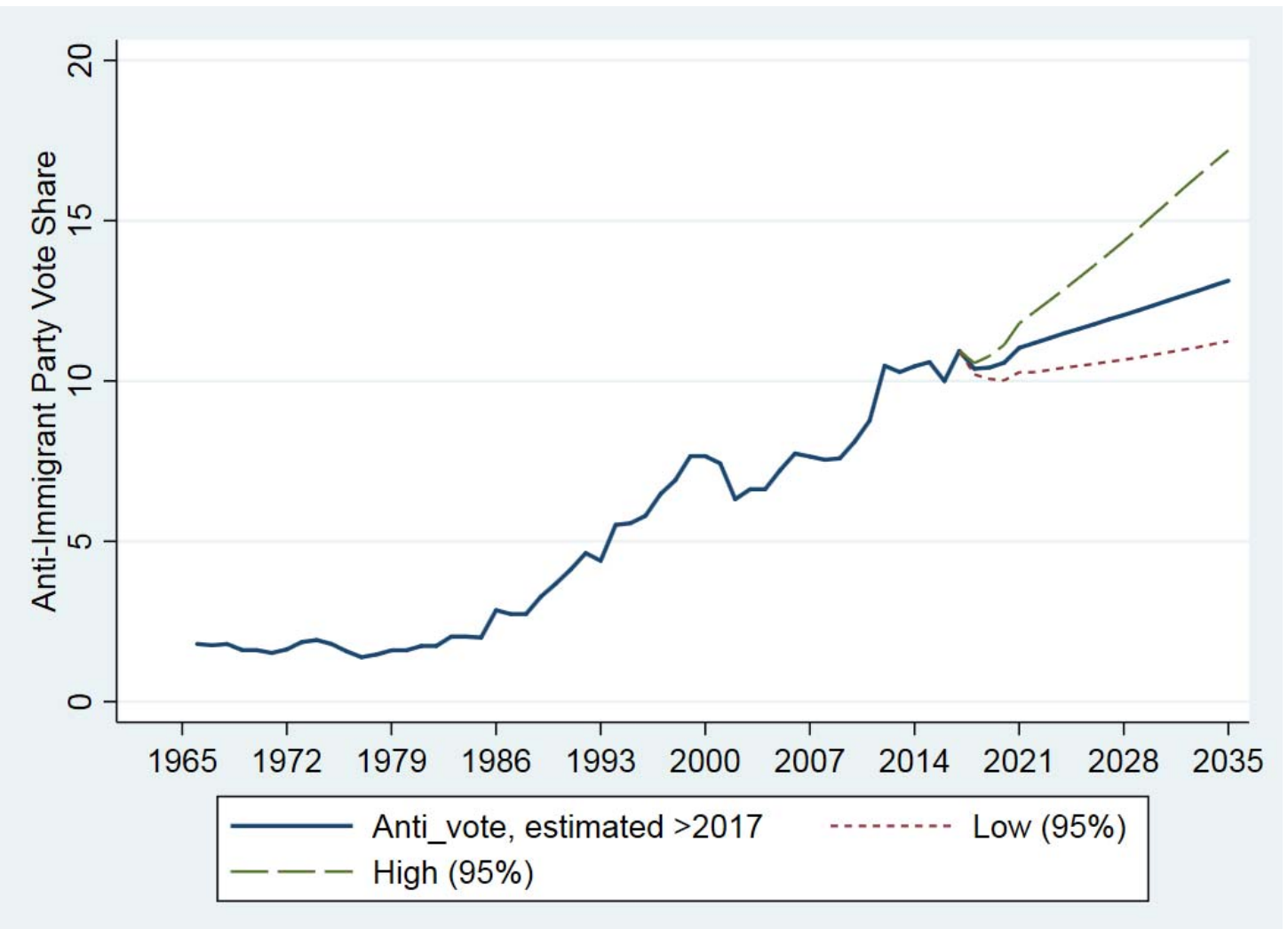

The high prediction in the long dashed line suggests $17 \%$ of the vote share on average across Western European countries by 2035, while the mid (solid line) and low (short dash) suggest 13 and $11 \%$ respectively. The latter is only about one point more in 2035 than 2018.

\section{Adjustment for Cohort Phases}

Comparing Western European political histories reveal two patterns in the trajectories of anti-immigrant parties. The first is that once these parties achieve 5\% of the vote share, they rarely drop below this amount in subsequent elections. The second is that once anti-immigrant parties enter the ballot and get any votes (even $0.1 \%$ ), they tend to eventually achieve $5 \%$ of the vote. The average time from first votes for an anti-immigrant party in an election and that party achieving $5 \%$ is 3.2 years. This is not a very precise average given that in some countries the party gets over 5\% in its first appearance, such as Denmark, France and Greece while in others it takes much longer, such as Belgium (13 years) and Finland ( 8 years). The history of anti-immigrant parties starts at very different periods, for example anti-immigrant parties had moderate support immediately 
after the Second World War in Austria and Switzerland and they only gained more than 5\% of vote shares in Greece and Germany after 2010, with the other countries falling in-between or not having any substantial vote share yet, as with Ireland, Spain and Portugal. I reorganize the time-series in each country so that it begins when anti-immigrant party success begins. Based on this reorganization, I qualitatively observe three cohort phases of anti-immigrant party development that take place during different times in each country. Figure 9 demonstrates these phases. After the anti-immigrant party gets $5 \%$ of the vote (time 0 in Figure 9), the early phase is characterized by sharp gains over a decade. The middle phase thereafter tends to be a lull with no gains over the next five years, Finally, the mature phase suggests stability and moderate gains over the next 15 years.

Figure 9. Cohort Trajectory Phases for Anti-Immigrant Party Vote Shares

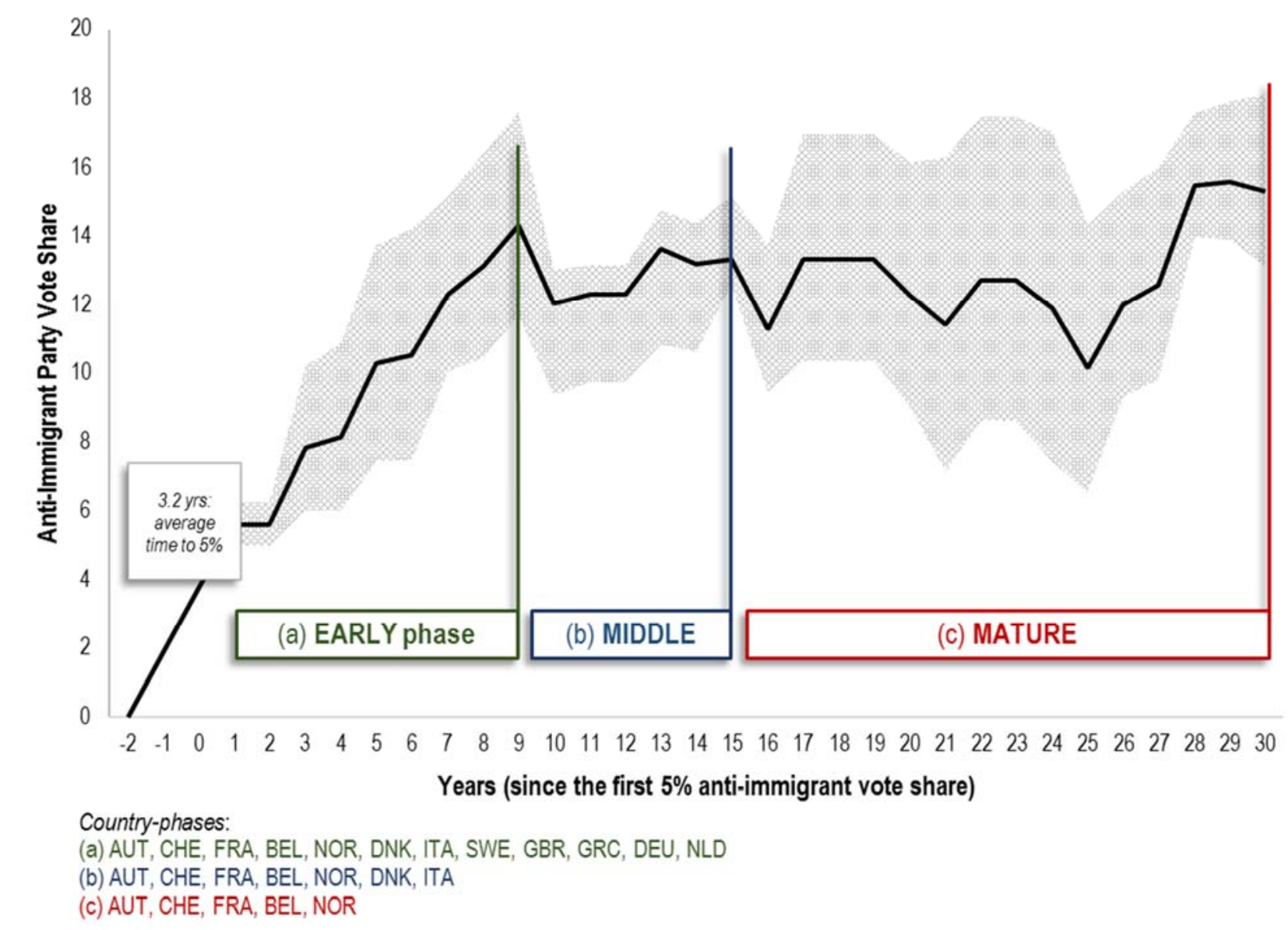

Applying phase averages based on when a country gets an anti-immigrant party on the ballot and in particular when that party gets over $5 \%$ of the vote I infer an alternative predictive model up to 2035 . Each prediction equals the outcome if each country follows the average phase trends experience by its peers over the course of 30 years. As each country starts its anti-immigrant party growth process in different years, this 30 year growth trend prediction starts at different times, and may leave some time points empty toward the end of the series. For example, Denmark crossed the 5\% mark in 1998, thus the prediction only covers up to 2027. However, I can link the linear predictions calculated in GLS regression to start of the 2027 time point and carry on until 2035. The new results on average for all of Western Europe appear as the dotted line in Figure 10. 
Figure 10. Anti-Immigrant Vote Share and Foreign-Born Predictions with Cohort Adjustment

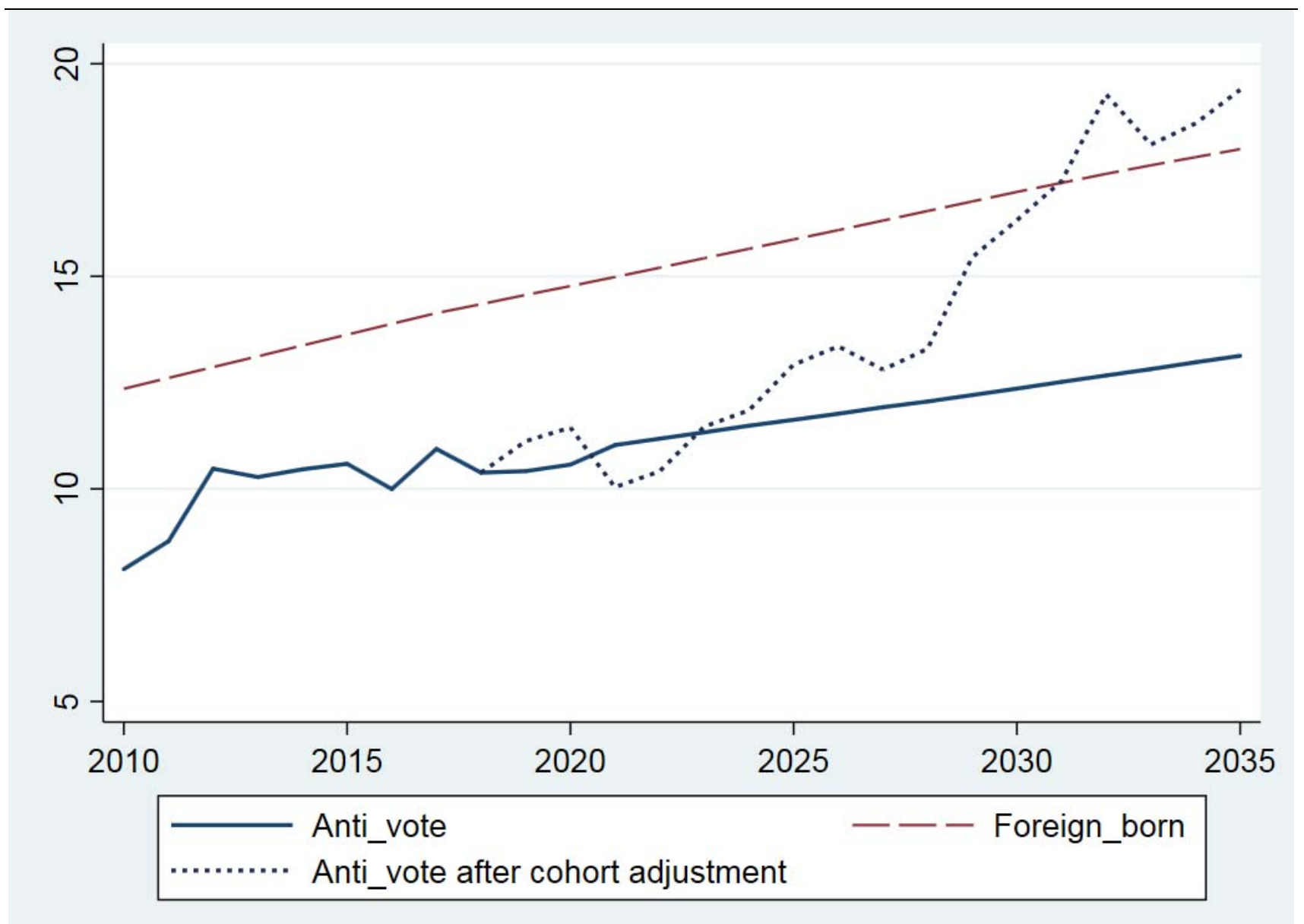

NOTE: Series observed from 2010-2017, predicted from 2018-2035.

If countries follow the phases of other countries anti-immigrant party vote shares on average, then the percentage of the national vote going to anti-immigrant parties in Western Europe on average should be almost $20 \%$.

\section{THE ROLE OF GROUP DYNAMICS AND THE FUTURE}

Using various methods of prediction, I come to similar conclusions. The first supports what theorists of anti-immigrant party success argue, that immigration is a necessary condition for anti-immigrant party successes. The steady increase in first generation immigrants in Western Europe is a significant predictor of anti-immigrant party vote share from 1962-2017 in both multilevel GLS regressions and when simulating shocks using vector autoregression. Given overwhelming evidence that the number of immigrants must increase in Western Europe from 2018-2035, I predict that anti-immigrant party share will also increase on average. This increase depends not only on immigration as it alone is not sufficient to explain anti-immigrant party success, but requires changes in productivity and aging as well. The lowest version of this prediction where foreign-born increases only little suggests a two-percentage point vote share increase from roughly 11 to $13 \%$ for antiimmigrant parties. The highest version suggests an increase to $17 \%$ (high confidence interval) and as high as 19\% (the cohort phase adjustment) by 2035 . 
I can only speculate what an increase of 11 to $19 \%$ of national votes going to anti-immigrant parties on average would mean for Western Europe. One way of quantifying this is to consider what changes came about as a result of anti-immigrant party successes thus far, and imagine them by a factor of 1.72 (i.e., the ratio of a change from 11 to 19\%). However, political power may be non-linear and is not easily quantified. There are thresholds at which anti-immigrant parties are necessary to form coalitions, gain important seats or nominations or at least have substantial minority veto power. Moreover, anti-immigrant voting is both an observed and latent indicator of what transpires in day-to-day social and political interactions. As an observed variable, it literally measures the amount of legitimate national power in the hands of parties whose positions are to remove, disparage or somehow denigrate ethnically and culturally minority segments of society. As a latent variable, it proximally measures racial and ethnic conflicts both in the public mind and at the street level resulting from group threat, nationalism, chauvinism, class and gender conflicts and in some cases neoliberalism (Cheong et al. 2007).

Thus far, anti-immigrant parties successfully ushered in policies disincentivizing inter-ethnic marriage, the construction of Mosques, and immigration flows'; a flood of these policy successes occurred in the mid2010s for example in Austria 2016 ${ }^{10}$, Sweden $2016^{11}$, Belgium 2015 ${ }^{12}$, Denmark 2016 ${ }^{13}$, Finland $2015^{14}$, the Netherlands $2013^{15}$ and Switzerland 2015-16 ${ }^{16}$. They also helped the UK vote to leave the EU, the left-wing Social Democrats in Sweden to introduce bureaucratic regulations against immigration and the first antiimmigrant party since the Nazis to gain $12.7 \%$ of German national votes. These changes especially affect displaced persons as they directly reduce or de facto remove a legal right to asylum guaranteed by the Geneva Convention. The parties have accomplished little else in terms of policy change or geopolitical upheaval, and even these aforementioned policy changes are small relative to their agendas (Akkerman 2012). Moreover, European public opinion about immigration has more positive trends and members of the public are often wellaware of the impending need for immigrant labor (Ceobanu and Koropeckyj-Cox 2013). Given that antiimmigrant parties hold only $11 \%$ of the national vote share on average across Western Europe as of 2017, it is perhaps not surprising that they did not accomplish more.

To the chagrin of refugees, immigrants and perhaps anyone hoping for social cohesion, anti-immigrant parties give a legitimate face to public opinions that are often not socially acceptable such as racism and xenophobia. However, voting for these parties also reflects native preference change, not just normalization of existing attitudes (Dahlström and Sundell 2012; Mudde 2010). For example, an amassing body of research demonstrates that greater immigrant presence predicts changes in welfare chauvinism measured as support of social policies

\footnotetext{
${ }^{9}$ For a collection of policies and news stories see http://www.statewatch.org/.

${ }^{10} \mathrm{http}$ ://www.asylumineurope.org/news/21-02-2017/aida-2016-update-austria

11 Stricter rules with shorter periods, family reunification and financial responsibility of applicants; https://www.nytimes.com/2016/06/22/world/europe/sweden-immigrant-restrictions.html

12 Restricted number of applications processed per day https://www.politico.eu/article/commission-complaint-belgiumrefugee-asylum-government-coalition/

${ }^{13}$ Various highly restrictive changes, asset seizures https://www.theatlantic.com/international/archive/2016/01/denmarkrefugees-immigration-law/431520/

${ }^{14}$ Removed automatic initial asylum for Iraqis https:/www.loc.gov/law/help/refugee-law/finland.php

${ }^{15}$ Delays in implementations https://www.loc.gov/law/help/immigration/Netherlands.php\#f2

${ }^{16}$ https://www.loc.gov/law/help/refugee-law/switzerland.php
} 
to benefit in-group members but not out-group members (Eger and Breznau 2017; Mewes and Mau 2012); nationalist policy preferences measured as opinions favoring the banning of foreign language or headscarves in public or disallowing the construction of minarets (Bay, Finseraas, and Pedersen 2013; Cummings-Bruce and Erlanger 2009); and reduced public support of universal welfare state provisions to the detriment of in-group as well as out-group members (Breznau and Eger 2016; Eger 2010; Schmidt-Catran and Spies 2016). Moreover, Manucci and Weber (2017) show that there was no strong media persuasion nor an increase in divisive populist messages among newspapers or anti-immigrant parties across several Western European countries since the 1970s. This suggests the voting impetus was not a product of media persuasion, but of preference changes. These preference changes allow policymakers across parties to pursue neoliberal, Euroskeptic or chauvinistic policies that weaken the social state, social solidarity and economic growth against the will of many workingclass anti-immigrant party voters (Röth, Afonso, and Spies 2017). This means that the anti-elite positions of many anti-immigrant parties in response to worsening conditions for the working-class in fact paly into the hands of the elite (Scruggs and Hayes 2017).

Essentially all of these anti-immigrant parties pursue some degree of populist nationalism that pushes for independent states within states, or retraction from supranational arrangements like the EU. This is a direct threat to institutions promoting peaceful trade, although they have not had the power to clearly undermine democratic institutions yet (Huber and Ruth 2017). Nonetheless, this makes the political landscape increasingly volatile, and European-wide volatility may pave ways for anti-immigrant parties to enter where none existed in democratic history as with Vox in Spain and National Renovator Party in Portugal. Populist parties are often entirely unprepared to legislate in areas such as education or infrastructure due to their often singularity in policy positions. Moreover, their divisive messages are an augury of war - or so they were the last time Europe was overrun with a populist party.

Many scholars predict that all nations will end up as liberal democracies either through rational adoption or institutional isomorphism (DiMaggio and Powell 1983; Fukuyama 1989). However, this is not happening. The democratic nation state is not taking prominence as the standard container of human societies. The alternatives coming out of events such as the Arab Spring, the rise of Communist China and a swath of the more democratic countries in the world becoming less democratic for the first time in history suggest a bleaker future ${ }^{17}$. At least under the assumption that authoritarianism is worse for societies than democracy.

The problem with predictions of standardization, consolidation or even peaceful cooperation overlook one of the most important features of human societies. That feature is group dynamics. As long as historical records exist, humans do not survive as solitary organisms and must organize themselves into groups. The most basic form of these groups comes from kinship. More advanced groups come from shared ideologies and histories. Drawing group boundaries and defending these group boundaries leads to conflict, especially as these

${ }^{17}$ https://www.economist.com/blogs/graphicdetail/2018/01/daily-chart-21 
boundaries are drawn around nations (Brewer 2001; Kaufmann 2008; Muller 2008; Smith 2001; Tajfel and Turner 1979; Tilly 1994).

Reduced trust, social capital and social cohesion are often hypothesized as a result of ethnic out-group size increase and diversification; however, in a review of 90 prominent studies, the findings inconclusively run in all directions (Meer and Tolsma 2014). Contact with out-group members increases intergroup trust and increasing immigrant presence increases the likelihood of contact; however, increasing presence in the absence of contact due to spatial segregation reduces intergroup trust, if not social trust in general (Hemker and Rink 2017; Rothstein and Stolle 2008). However, the rise in anti-immigrant party votes is a proxy for nationalism and the group conflicts brewing in Western European societies. In fact, looking to Eastern Europe reveals that increases in the percentage of first generation immigrants is unlikely the main cause of voting. To the East, a wave of European populism and authoritarianism takes place where there are little or no refugees, few Muslim immigrants or even few immigrants in general. Although immigration rose in several of these Eastern countries over the past decade (Rovny 2014), it might be the specter of immigration, not only its manifestation that helps drive voting. 


\section{REFERENCES}

Abbott, Ryan and Bret N. Bogenschneider. 2018. "Should Robots Pay Taxes? Tax Policy in the Age of Automation." Harvard Law \& Policy Review (forthcoming).

Agafiţei, Mihaela and Georgiana Ivan. 2016. First and Second-Generation Statistics on Main Characteristics. Table 1. Proportion of immigrant population in total resident population by resident country, $2014, \%$. Akkerman, Tjitske. 2012. "Comparing Radical Right Parties in Government: Immigration and Integration Policies in Nine Countries (1996-2010).” West European Politics 35(3):511-29.

Art, David. 2011. Inside the Radical Right: The Development of Anti-Immigrant Parties in Western Europe. Cambridge University Press.

Autor, David H. 2015. "Why Are There Still So Many Jobs? The History and Future of Workplace Automation." Journal of Economic Perspectives 29(3):3-30.

Bay, Ann-Helén, Henning Finseraas, and Axel West Pedersen. 2013. "Welfare Dualism in Two Scandinavian Welfare States: Public Opinion and Party Politics.” West European Politics 36(1):199-220.

Berg, Justin Allen. 2015. "Explaining Attitudes toward Immigrants and Immigration Policy: A Review of the Theoretical Literature." Sociology Compass 9(1):23-34.

Brewer, Marilynn B. 2001. "Ingroup Identification and Intergroup Conflict: When Does Ingroup Love Become Outgroup Hate?” in Social Identity, Intergroup Conflict, and Conflict Reduction, edited by R. Ashmore, D. Jussim, and D. Wilder. New York: Oxford University Press.

Breznau, Nate and Maureen A. Eger. 2016. "Immigrant Presence, Group Boundaries, and Support for the Welfare State in Western European Societies.” Acta Sociologica 59(3):195-214.

Broadbent, E., R. Stafford, and B. MacDonald. 2009. "Acceptance of Healthcare Robots for the Older Population: Review and Future Directions.” International Journal of Social Robotics 1(4):319. van der Brug, Wouter, Meindert Fennema, and Jean Tillie. 2000. "Anti-Immigrant Parties in Europe: Ideological or Protest Vote?” European Journal of Political Research 37(1):77-102.

van der Brug, Wouter and Fennema Meindert. 2003. "Protest or Mainstream? How the European AntiImmigrant Parties Developed into Two Separate Groups by 19991.” European Journal of Political Research 42(1):55-76.

Castles, Stephen. 2006. "Guestworkers in Europe: A Resurrection?" International Migration Review 40(4):741-66.

Ceobanu, Alin M. and Tanya Koropeckyj-Cox. 2013. "Should International Migration Be Encouraged to Offset Population Aging? A Cross-Country Analysis of Public Attitudes in Europe." Population Research and Policy Review 32(2):261-84.

Cheong, Pauline Hope, Rosalind Edwards, Harry Goulbourne, and John Solomos. 2007. "Immigration, Social Cohesion and Social Capital: A Critical Review." Critical Social Policy 27(1):24-49.

Cochrane, Christopher and Neil Nevitte. 2014. "Scapegoating: Unemployment, Far-Right Parties and AntiImmigrant Sentiment." Comparative European Politics 12(1):1-32.

Cummings-Bruce, Nick and Steve Erlanger. 2009. "Swiss Ban Building of Minarets on Mosques.” New York 
Times, November 29, A6.

Cutts, David, Robert Ford, and Matthew J. Goodwin. 2011. "Anti-Immigrant, Politically Disaffected or Still Racist after All? Examining the Attitudinal Drivers of Extreme Right Support in Britain in the 2009 European Elections." European Journal of Political Research 50(3):418-40.

Dahlström, Carl and Anders Sundell. 2012. "A Losing Gamble. How Mainstream Parties Facilitate AntiImmigrant Party Success." Electoral Studies 31(2):353-63.

Demeny, Paul. 2003. "Population Policy Dilemmas in Europe at the Dawn of the Twenty-First Century." Population and Development Review 29(1):1-28.

DiMaggio, Paul J. and Walter W. Powell. 1983. "The Iron Cage Revisited: Institutional Isomorphism and Collective Rationality in Organizational Fields.” American Sociological Review 48(2):147-60.

Döring, Holger and Philip Manow. 2016. Parliaments and Governments Database: Information on Parties, Elections and Cabinets in Modern Democracies. Development version, accessed 10.10.2017.

Ebbinghaus, Bernhard and Noel Whiteside. 2012. "Shifting Responsibilities in Western European Pension Systems: What Future for Social Models?" Global Social Policy 12(3):266-82.

Eger, Maureen A. 2010. "Even in Sweden: The Effect of Immigration on Support for Welfare State Spending." European Sociological Review 26(2):203-17.

Eger, Maureen A. and Andrea Bohman. 2016. "The Political Consequences of Contemporary Immigration." Sociology Compass 10(10):877-92.

Eger, Maureen A. and Nate Breznau. 2017. "Immigration and the Welfare State: A Cross-Regional Analysis of European Welfare Attitudes." International Journal of Comparative Sociology 58(5):440-63.

Eger, Maureen A. and Sarah Valdez. 2015. "Neo-Nationalism in Western Europe." European Sociological Review 31(1):115-30.

Eurostat. 2018. Assumptions for Net Migration. Luxembourg.

Freeman, John R., John T. Williams, and Tse-min Lin. 1989. "Vector Autoregression and the Study of Politics." American Journal of Political Science 33(4):842-77.

Fukuyama, Francis. 1989. "The End of History?” The National Interest (16):3-18.

Golder, Matt. 2016. "Far Right Parties in Europe." Annual Review of Political Science 19(1):477-97.

Hainmueller, Jens and Daniel J. Hopkins. 2014. "Public Attitudes Toward Immigration." Annual Review of Political Science 17(1):225-49.

Halal, William, Jonathan Kolber, and Owen Davies. 2016. "Forecasts of AI and Future Jobs in 2030: Muddling Through Likely, with Two Alternative Scenarios." Journal of Future Studies 21(2):83-96.

Halla, Martin, Alexander F. Wagner, and Josef Zweimüller. 2017. "Immigration and Voting for the Far Right." Journal of the European Economic Association 15(6):1341-85.

Hemker, Johannes and Anselm Rink. 2017. "Multiple Dimensions of Bureaucratic Discrimination: Evidence from German Welfare Offices.” American Journal of Political Science 61(4):786-803.

Hjerm, Mikael. 1998. "National Identities, National Pride and Xenophobia: A Comparison of Four Western Countries." Acta Sociologica 41(4):335-47.

Huber, Robert A. and Saskia P. Ruth. 2017. "Mind the Gap! Populism, Participation and Representation in Europe." Swiss Political Science Review 23(4):462-84. 
Kaufmann, Eric. 2008. "The Lenses of Nationhood: An Optical Model of Identity.” Nations and Nationalism 14(3):449-77.

Knigge, Pia. 1998. "The Ecological Correlates of Right-Wing Extremism in Western Europe.” European Journal of Political Research 34(2):249-79.

Lütkepohl, Helmut. 2005. New Introduction to Multiple Time Series Analysis. Berlin: Springer.

Manucci, Luca and Edward Weber. 2017. "Why The Big Picture Matters: Political and Media Populism in Western Europe since the 1970s." Swiss Political Science Review 23(4):313-34.

Meer, Tom van der and Jochem Tolsma. 2014. "Ethnic Diversity and Its Effects on Social Cohesion." Annual Review of Sociology 40(1).

Mewes, Jan and Steffen Mau. 2012. "Unraveling Working-Class Welfare Chauvinism.” Pp. 119-57 in Contested Welfare States: Welfare Attitudes in Europe and Beyond, edited by S. Svallfors. Stanford: Stanford University Press.

Mudde, Cas. 2010. “The Populist Radical Right: A Pathological Normalcy.” West European Politics 33(6):1167-86.

Muller, Jerry Z. 2008. "Us and Them: The Enduring Power of Ethnic Nationalism.” Foreign Affairs 87(2):1835.

OECD. 2010. OECD Factbook 2010: Economic, Environmental and Social Indicators. Paris: OECD Publishing.

OECD. 2017a. GDP Long-Term Forecast, 2009-2060. Long-term baseline projections.

OECD. 2017b. International Migration Outlook 2017. Updated 08.06.2017.

OECD. 2017c. Population (Indicator). Accessed 18.10.2018.

OECD. 2018. Gross Domestic Product (Indicator). Accessed 26.02.2018.

Özden, Çağlar, Christopher R. Parsons, Maurice Schiff, and Terrie L. Walmsley. 2011. "Where on Earth Is Everybody? The Evolution of Global Bilateral Migration 1960-2000.” The World Bank Economic Review 25(1):12-56.

Pehrson, Samuel, Rupert Brown, and Hanna Zagefka. 2009. "When Does National Identification Lead to the Rejection of Immigrants? Cross-Sectional and Longitudinal Evidence for the Role of Essentialist InGroup Definitions." British Journal of Social Psychology 48(1):61-76.

Pierson, Paul. 2000. "Increasing Returns, Path Dependence, and the Study of Politics.” The American Political Science Review 94(2):251-67.

Reeskens, Tim and Matthew Wright. 2013. "Nationalism and the Cohesive Society: A Multilevel Analysis of the Interplay Among Diversity, National Identity, and Social Capital Across 27 European Societies ." Comparative Political Studies 46(2):153-81.

Röth, Leonce, Alexandre Afonso, and Dennis C. Spies. 2017. "The Impact of Populist Radical Right Parties on Socio-Economic Policies.” European Political Science Review 1-26.

Rothstein, Bo and Dietlind Stolle. 2008. "The State and Social Capital: An Institutional Theory of Generalized Trust." Comparative Politics 40(4):441-59.

Rovny, Jan. 2014. “The Other 'Other': Party Responses to Immigration in Eastern Europe.” Comparative 
European Politics 12(6):637-62.

Rydgren, Jens. 2005. "Is Extreme Right-wing Populism Contagious? Explaining the Emergence of a New Party Family." European Journal of Political Research 44(3):413-37.

Schmidt-Catran, Alexander W. and Dennis C. Spies. 2016. "Immigration and Welfare Support in Germany." American Sociological Review .

Scruggs, Lyle and Thomas J. Hayes. 2017. "The Influence of Inequality on Welfare Generosity.” Politics \& Society 45(1):35-66.

Sims, Christopher A. 1980. "Macroeconomics and Reality." Econometrica 48(1):1-48.

Smith, Anthony D. 2001. Nationalism: Theory, Ideology, History. Cambridge: Polity Press.

Tajfel, Henri and John C. Turner. 1979. “An Integrative Theory of Intergroup Conflict.” P. 49 in The Social Psychology of Intergroup Relations, edited by W. G. Austin and S. Worchel. Monterey, CA: BrooksCole.

Tilly, Charles. 1994. "States and Nationalism in Europe 1492-1992." Theory and Society 23(1):131-146 CRCopyright \&\#169; 1994 Springer.

UN. 2001. Replacement Migration: Is It a Solution to Declining and Ageing Populations. New York:

Population Division Department of Economic and Social Affairs United Nations Secretariat.

UN. 2017. World Population Prospects. Total Population Predictions by Age.

Wessendorf, Susanne. 2008. "Culturalist Discourses on Inclusion and Exclusion: The Swiss Citizenship Debate." Social Anthropology 16(2):187-202. 


\section{APPENDIX}

Table 2. Anti-Immigrant Parties by Country

\begin{tabular}{|c|c|c|}
\hline country & party name & English name \\
\hline Austria & Freiheitliche Partei Österreichs & Freedom Party of Austria \\
\hline Belgium & $\begin{array}{l}\text { Vaams Blok } \\
\text { Front National } \\
\text { Nationale Aktion - Action Nationale | Schweizer } \\
\text { Demokraten - Démocrates Suisses }\end{array}$ & $\begin{array}{l}\text { Flemish Block } \\
\text { National Front } \\
\text { National Action -- Swiss Democrats }\end{array}$ \\
\hline Denmark & Dansk Folkeparti & Danish Peoples Party \\
\hline Spain & Vox & Voice \\
\hline Finland & Suomen Puolue - Perussuomalaiset & Finnish Party-- True Finns \\
\hline France & Front national & National Front \\
\hline Germany & $\begin{array}{l}\text { Nationaldemokratische Partei Deutschlands } \\
\text { Alternative für Deutschland } \\
\text { Die Republikaner } \\
\text { Alternative für Deutschland }\end{array}$ & $\begin{array}{l}\text { National Democratic Party } \\
\text { Alternative for Germany } \\
\text { The Republicans } \\
\text { Alternative for Germany }\end{array}$ \\
\hline Greece & $\begin{array}{l}\text { Anexartitoi Ellines } \\
\text { Laikos Syndesmos - Chrysi Avg } \\
\text { Enosi Gia Tin Patrida Kai Ton Lao }\end{array}$ & $\begin{array}{l}\text { Independent Greeks } \\
\text { Peoples Association -- Golden Dawn } \\
\text { Union for the Homeland and the People }\end{array}$ \\
\hline Ireland & Identity Ireland & Identity Ireland \\
\hline Iceland & Íslenska pjóðfylkingin & Icelandic National Front \\
\hline Italy & $\begin{array}{l}\text { Lega Nord } \\
\text { Alleanza Nazionale }\end{array}$ & $\begin{array}{l}\text { Northern League } \\
\text { National Alliance }\end{array}$ \\
\hline Luxembourg & Biergerlëscht-Liste des citoyens & Citizens' List \\
\hline The Netherlands & $\begin{array}{l}\text { Partij voor de Vrijheid } \\
\text { Forum voor Democratie }\end{array}$ & $\begin{array}{l}\text { Party for Freedom } \\
\text { Forum for Democracy }\end{array}$ \\
\hline Norway & Fremskrittspartiet & Progress Party \\
\hline Sweden & Sverigedemokraterna & Sweden Democrats \\
\hline Switzerland & $\begin{array}{l}\text { Schweizerische Volkspartei - Union } \\
\text { Démocratique du Centre }\end{array}$ & Swiss People's Party \\
\hline Great Britain & $\begin{array}{l}\text { United Kingdom Independence Party } \\
\text { British National Party }\end{array}$ & $\begin{array}{l}\text { United Kingdom Independence Party } \\
\text { British National Party }\end{array}$ \\
\hline
\end{tabular}


Table 3. Results of Multilevel GLS Regression Predicting Foreign-born, Western Europe 1962-2017

\begin{tabular}{|c|c|c|c|c|c|}
\hline \multicolumn{4}{|l|}{ Fixed-parameters (B) } & \multicolumn{2}{|c|}{$95 \%$ conf. interval } \\
\hline variable & b & s.e. & $p$ & low & high \\
\hline Counter & 0.16 & 0.03 & 0.000 & 0.11 & 0.22 \\
\hline constant & 1.31 & 1.77 & 0.461 & -2.16 & 4.77 \\
\hline Random-parameters (u) & var & s.e. & & low & high \\
\hline Aged & 0.59 & 0.13 & & 0.38 & 0.92 \\
\hline Counter & 0.11 & 0.02 & & 0.07 & 0.17 \\
\hline intercepts & 6.82 & 1.41 & & 4.55 & 10.23 \\
\hline Model Statistics & $\mathrm{N}(\mathrm{i})$ & $N(j)$ & e-variance & & \\
\hline values & 952 & 17 & 1.177 & & \\
\hline
\end{tabular}


Table 4. Results of Multilevel GLS Regression Predicting Anti-Immigrant

Party Vote Share, Western Europe 1962-2017

\begin{tabular}{rccccc}
\hline $\begin{array}{r}\text { Fixed-parameters (B) } \\
\text { variable }\end{array}$ & b & s.e. & p & low & high \\
\hline Aged & 0.60 & 0.10 & 0.000 & 0.40 & 0.80 \\
GDP & 0.22 & 0.03 & 0.000 & 0.16 & 0.27 \\
constant & 2.79 & 1.65 & 0.090 & -0.43 & 6.02 \\
\hline Random-parameters (u) & var & s.e. & low & high \\
\hline GDP_growth & 1402.48 & 662.16 & & 555.92 & 3538.19 \\
Foreign_born & 5.09 & 2.00 & & 2.36 & 10.98 \\
Foreign_anti & 4.64 & 1.77 & & 2.19 & 9.79 \\
intercepts & 40.31 & 15.72 & & 18.78 & 86.55 \\
\hline Model Statistics & $\mathrm{N}(\mathrm{i})$ & $\mathrm{N}(\mathrm{j})$ & e-variance & & \\
\cline { 1 - 4 } & 867 & 17 & 7.902 & & \\
\hline
\end{tabular}


Figure 7. Author's and Eurostat-implied Estimates of Foreign-Born Population, 2018-2035

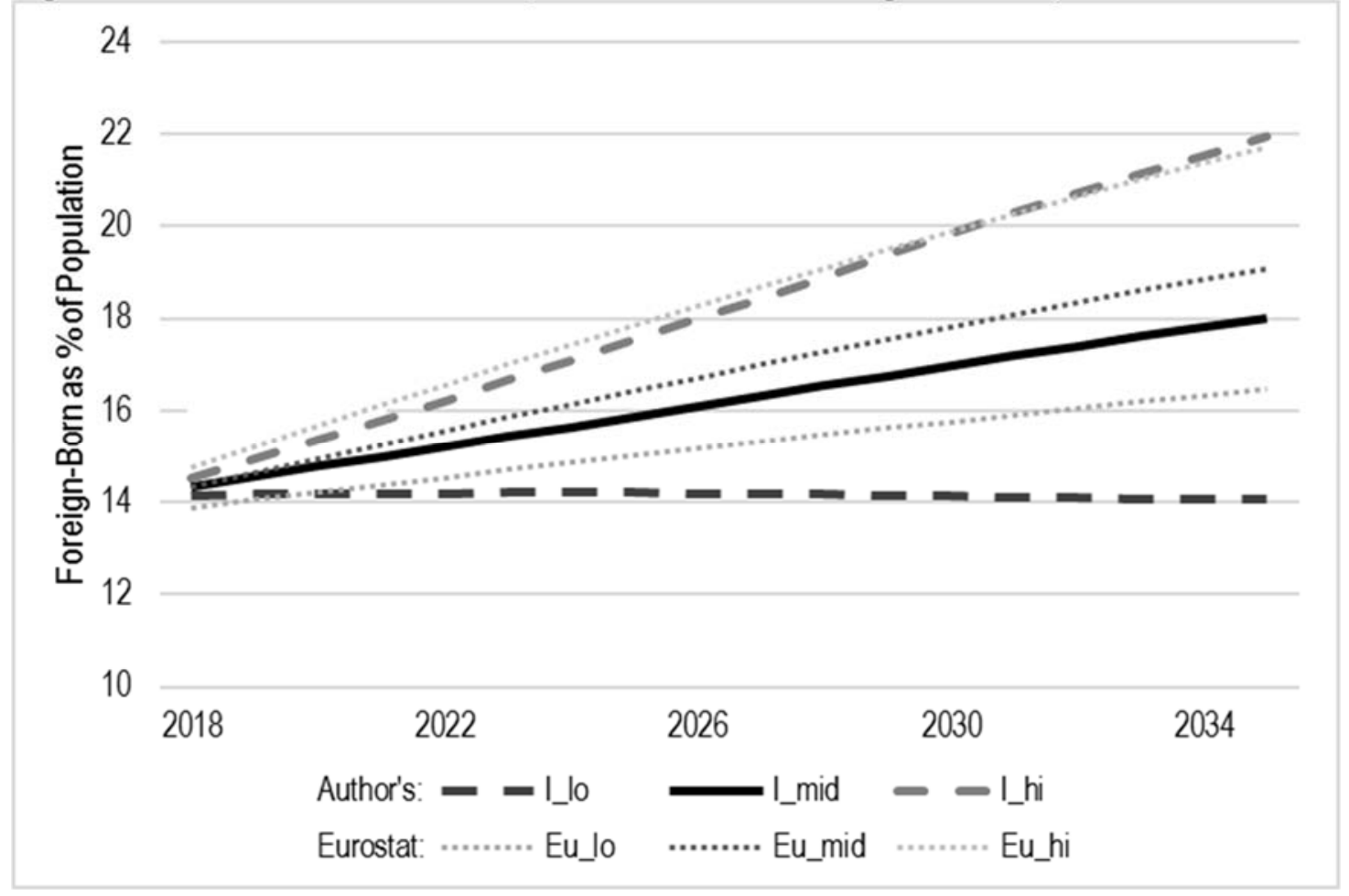

